\title{
SARCOPLASMATIC AND MYOFIBRILLAR PROTEIN CHANGES CAUSED BY ACUTE HEAT STRESS IN BROILER CHICKEN
}

Carolina de Castro Santos ${ }^{1}$; Eduardo Francisquine Delgado ${ }^{2 *}$; José Fernando Machado Menten $^{3}$; Aparecida Carla de Moura Pedreira ${ }^{4}$; Carmen Josefina Contreras Castillo ${ }^{5}$; Gérson Barreto Mourão $0^{6}$; Camila Brossi ${ }^{7}$; Iran José Oliveira da Silva ${ }^{8}$

${ }^{l}$ USP/ESALQ - Programa de Pós-Graduação em Ciência Animal e Pastagens.

${ }^{2}$ USP/ESALQ - Depto. Zootecnia - Lab. de Anatomia e Fisiologia Animal, C.P. 09 - 13418-900 - Piracicaba, SP Brasil.

${ }_{4}^{3} U S P / E S A L Q-$ Depto. Zootecnia.

${ }^{4} R$. Francisco C. do Nascimento, 50 - 13405-021-Piracicaba, SP - Brasil.

${ }^{5} U S P / E S A L Q$ - Depto. de Agroindústria, Alimentos e Nutrição.

${ }^{6}$ USP/ESALQ - Depto. de Matemática e Estatística.

${ }^{7}$ USP/ESALQ - Programa de Pós-Graduação em Ciência e Tecnologia de Alimentos.

${ }^{8}$ USP/ESALQ/NUPEA - Depto. de Engenharia Rural.

*Corresponding author <efdelgad@esalq.usp.br>

ABSTRACT: Acute heat stress (AHS) modifies the structure of myofibrils affecting functional properties of meat, mainly the water holding capacity. This experiment aimed to identify changes in proteolysis and migration between the myofibrillar and sarcoplasmatic fractions due to pre-slaughter AHS. Myofibrillar fragmentation index (MFI), SDS-PAGE, western blot of vinculin (WB) and shear force (SF) were determined. Six hundred broilers (Gallus gallus) were slaughtered in three different days (ST). In each ST, groups of ten animals were placed in transport crates and submitted to AHS $\left(35^{\circ} \mathrm{C}, 75-85 \% \mathrm{RH}\right)$ for 2 hours. Simultaneously, the non-stressed broilers (NS) were kept in thermoneutral environment $\left(22^{\circ} \mathrm{C}, 83 \pm 6.6 \% \mathrm{RH}\right)$ within the crates in the same density. After slaughter, the breast muscles were kept refrigerated until the withdrawal of all samples $(0,1,2,6$ and 24 hours after slaughter). Sampling within AHS and NS birds was collected according to lightness value (normal $L^{*} \leq 49$, and high $\geq 51$ ), except for determination of MFI and SF. The lightness was used later to perform SDS-PAGE and WB analyses. MFI kinetics showed that the fragmentation rate was superior in animals NS, indicating that AHS can harm proteolysis and rate of myofibrillar fragmentation. However, the extent of fragmentation did not change, as well as SF values. SDS-PAGE for Troponin fragments indicated a differentiated pattern between AHS and NS. The WB did not show alterations in vinculin fragmentation. Modifications in sarcoplasmatic fraction are observed in meat with high $\mathrm{L}^{*}$ values, independent of environmental condition.

Key words: broiler, heat stress, lightness, fragmentation index, shear force

\section{ALTERAÇÕES NAS PROTEÍNAS SARCOPLASMÁTICAS E MIOFIBRILARES EM FRANGOS DE CORTE CAUSADAS POR ESTRESSE TÉRMICO AGUDO}

RESUMO: O estresse térmico agudo (ET) causa alterações na estrutura das miofibrilas, afetando propriedades funcionais da carne, principalmente a capacidade de retenção de água. Identificaram-se mudanças na proteólise e migração entre as frações miofibrilar e sarcoplasmática, decorrentes do ET pré-abate, através do índice de fragmentação miofibrilar (MFI), SDS-PAGE para troponina (SDS), imunodetecção de vinculina (IV) e força de cisalhamento (FC). Seiscentos frangos (Gallus gallus) foram abatidos em três dias diferentes (DA). Em cada DA os animais foram colocados em caixas de transporte (10 aves/caixa) e submetidos a ET ( $35^{\circ} \mathrm{C}, 75-85 \%$ UR)por 2 horas. Simultaneamente, o outro grupo de animais (NET) foi mantido em caixas em condição termoneutra $\left(22^{\circ} \mathrm{C}, 83 \pm 6,6 \% \mathrm{UR}\right)$ pelo mesmo período de tempo. Após o abate o músculo do peito foi coletado e mantido refrigerado, até a retirada de todas as amostras $\left(0,1,2,6\right.$ e 24 horas pós-abate). $\mathrm{O}$ valor de luminosidade ( $\mathrm{L}^{*} \leq 49$, normal e $\geq 51$, alto), foi o parâmetro utilizado na amostragem para SDS e IV. A cinética do MFI demonstrou que a taxa de fragmentação foi superior nos animais NET, indicando que o estresse térmico pode prejudicar 
o processo de proteólise. Entretanto, a extensão da fragmentação não variou, bem como os valores de FC. No SDS ocorreram padrões diferenciados de fragmentação entre aves ET e NET. Modificações na fração sarcoplasmática foram observadas em amostras com $\mathrm{L}^{*}$, independentemente da condição ambiental.

Palavras-chave: frangos de corte, estresse térmico, luminosidade, índice de fragmentação, força de cisalhamento

\section{INTRODUCTION}

Some proteins are involved in structure and elasticity of myofibrils and are related with processes of proteolysis, solubilization, oxidation and denaturation that determine the characteristics of the meat product. Acute heat stress (AHS) has been related to alterations in the functional properties (color, water holding capacity) of turkey meat (Pietrzak et al., 1997). Water holding capacity seems to be related with the integrity of myofibrillar structure (Hamm, 1960; Honikel \& Reagan, 1986). Moreover, broilers reared at $34^{\circ} \mathrm{C}$ had lower carcass and breast yield, moisture and protein content (Aksit et al., 2006).

One way to verify alterations in the protein functionality of the meat is through the value of lightness $\left(\mathrm{L}^{*}\right)$, that has high correlation with the conditions of pale, soft and exudative (PSE) meat (Barbut, 1993). The higher the value of $\mathrm{L}^{*}$, the lower is the water holding capacity (McCurdy et al., 1996; Sosnicki et al., 1998). Values of $L^{*}>49$ are indicative of meat with alterations in the functionality of proteins (Barbut, 1997). Besides color and water holding capacity, denaturation (Briskey, 1964) and oxidation (Nakashima et al., 2004) caused by AHS may harm the process of proteolysis and therefore, tenderness (Wood \& Richards, 1975).

Proteins as Troponin T, important constituent of myofibrillar proteins (Hedrick, 1994), are easily degraded in the proteolytic process (MacBride \& Parrish, 1977; Olson \& Parrish, 1976). Vinculin (citoskeletal protein) keeps the structure of myofibrils, and also suffer postmortem proteolysis (Taylor et al., 1995). Therefore, these myofibrillar proteins are good candidates for verification of modifications of the proteolytic process. Furthermore, migration of proteins between myofibrillar and sarcoplasmatic fractions has also been verified in turkey or pork meats showing PSE (Pietrzak et al., 1997)

The objective of this study is to identify changes in myofibrillar proteolysis and migration between muscle protein fractions and its relations with the meat lightness for chicken breast from birds under pre-slaughter heat stress.

\section{MATERIAL AND METHODS}

\section{Animals}

One day chicklings (600 birds) from the Cobb commercial line were allocated in an experimental bird housing. They were raised in mixed groups, in the density of 12 birds $\mathrm{m}^{-2}$, with food and water ad libitum, until 40, 42 and 44 days of age, when they reached average weights of $2.8,3.0$ e $3.2 \mathrm{~kg}$, respectively.

The slaughter of the broilers occurred in experimental abattoir on three different days according to bird age. One day before the first slaughter date, the birds were randomly divided in groups of 200 and kept in the same environment. Before each slaughter date, broilers were submitted to eight hours of fasting.

At each slaughter date, birds were placed in transport crates (ten birds per crate $^{-1}$ ). Two crates were sent to acute heat stress (AHS) treatment in a climatic chamber $\left(35^{\circ} \mathrm{C} ; 75-85 \%\right.$ Relative Humidity - $\mathrm{RH}$, for $2 \mathrm{~h}$ ) and the other crates remained in the bird housing under thermoneutral conditions $\left(22^{\circ} \mathrm{C}\right.$; $83 \pm 6.6 \% \mathrm{RH}$, for two hours), composing the nonstressed (NS) group. The crates entered the chamber in pairs, until a total of ten crates passed by the climatic chamber, while the NS counterparts remained at the bird housing. After the heat exposure, the crates were taken from the climatic chamber and transported in a closed car for $200 \mathrm{~m}$ to the abattoir. The crates with the NS groups were carried in the same car. The birds were slaughtered within 10 minutes after having been taken out of the climatic chamber.

\section{Muscle sampling}

After slaughter, the broilers were plucked, kept in a chiller for $30 \mathrm{~min}$ (until the internal temperature reach $0-2^{\circ} \mathrm{C}$ ) and then, eviscerated. They were weighed, cut in parts and the breast muscles (Pectoralis major - AHS and NS) were collected for accomplishment of the analyses. The muscle lightness value $\left(\mathrm{L}^{*}\right)$ was used to identify the samples $\left(\mathrm{L}^{*}\right.$ $\leq 49$, normal, $\mathrm{L}^{*} \geq 51$, high), which were used latter to perform the analyses of SDS-PAGE and Western blot. For the determinations of the MFI and SF, the value of $L^{*}$ was not a determinant factor. The evaluation of $\mathrm{L}^{*}$ was obtained using the colorimeter Minolta Chroma Meter CR-508d according to the CIELAB system, after the separation of the breast from the carcass, approximately 10 to 15 minutes after the chilling process. Forty minutes after slaughter the first sample (Time 0) was collected. The breasts were packed in plastic bags and kept in boxes 
with ice, until the extraction of all the samples $(1,2$, 6 and 24 hours after slaughter). All samples were frozen immediately after their collection, and kept in liquid nitrogen until analyses.

\section{Myofibrillar Fragmentation Index (MFI)}

MFI determination was made according to the procedure of Culler et al. (1978) with some modifications as follows: $3 \mathrm{~g}$ of muscle samples were homogenized with a Waring blender at $10000 \mathrm{rpm}$, for 30 seconds in 10 volumes $(\mathrm{v} / \mathrm{w})$ of MFI buffer (100 $\mathrm{mM} \mathrm{KCl}, 20 \mathrm{mM} \mathrm{KH}_{2} \mathrm{PO}_{4}, 20 \mathrm{mM} \mathrm{K} \mathrm{HPO}_{4}, 1 \mathrm{mM}$ EDTA, $1 \mathrm{mM} \mathrm{MgCl}_{2}$, $\mathrm{pH} 7.0,1 \mathrm{mM} \mathrm{NaN}_{3}$ ) at $4^{\circ} \mathrm{C}$. The myofibril suspension was filtered through a strain and kept in refrigerator $\left(4^{\circ} \mathrm{C}\right)$. The protein concentration of the myofibril solution was determined by the biuret method (Gornall et al., 1949). Two dilutions $\left(0.75\right.$ and $\left.1.5 \mathrm{mg} \mathrm{mL}^{-1}\right)$ in a final volume of 8 $\mathrm{mL}$ were used for MFI determinations. The absorbance at $540 \mathrm{~nm}$ was measured in a Coleman 295 Spectrophotometer, and the index calculated according to Culler et al. (1978).

\section{Shear force (SF)}

For this analysis the breasts ( $24 \mathrm{~h}$ after slaughter) were kept in laminated bags and heated in an electric grill to a final internal temperature of $82^{\circ} \mathrm{C}$. Then, they were chilled for $24 \mathrm{~h}$ under $2 \pm 1^{\circ} \mathrm{C}$. After the storage the breasts were cut in pieces of $2.0 \times 1.0 \times$ $1.0 \mathrm{~cm}$, according to Froning \& Uijtteenboogaart (1988). The samples, with the fibers directed perpendicularly to foils were sheared with a texturometer Texture Test System, label FTC, model TP2, joined to a Warner Braztler blade, velocity $20 \mathrm{~cm} \mathrm{~min}^{-1}$ and 100 $\mathrm{kg}$ weight.

\section{Protein functionality}

\section{Extraction of myofibrillar and sarcoplasmatic frac- tions}

Two grams of muscle were homogenized in three volumes of homogenizing buffer $(100 \mathrm{mM}$ Tris$\mathrm{HCl}, \mathrm{pH} 8.3$ at $4^{\circ} \mathrm{C}, 10 \mathrm{mM}$ EDTA, $10 \mathrm{mM} 2-$ mercaptoethanol and a cocktail of proteases inhibitors: leupeptin $=6 \mathrm{mg} \mathrm{L}^{-1}$, ovomucoid $=100 \mathrm{mg} \mathrm{L}^{-1}$ and phenylmethylsulfonyl - PMSF $=2 \mathrm{mM}$ ). Minced tissue was homogenized with a polytron, three times at high speed, each for 30 seconds. This homogenate was centrifuged at $37.500 \mathrm{~g}_{\max }$ for 120 minutes. After this, samples of the supernatant were collected to determine total protein with the biuret method. The same was done with the pellet. The samples were heated until $95^{\circ} \mathrm{C}$ for 5 minutes with Laemmli buffer (Laemmli, 1970) and then, kept frozen in $-20^{\circ} \mathrm{C}$ until their utilization in the gel loading.

\section{SDS PAGE and Western blotting}

For electrophoresis, $50 \mu \mathrm{g}$ of protein for each sample from the pellet were loaded on the polyacrilamide (37.5:1) gels (mini-gels). For Troponin were used 12\% and for Vinculin 9\% resolving gels, with 4\% stacking gel, through Mini Protean II system (Bio-Rad). Protein standards used were Prestained SDS-PAGE Standards Low Range (Bio-Rad) for Troponin and Prestained SDS-PAGE Standards Broad Range (Bio-Rad) for Vinculin. Gels were run at $120 \mathrm{~V}$ for approximately 90 minutes.

For the western blot for Vinculin, proteins in the gel were transferred in buffer containing $25 \mathrm{mM}$ Tris- $\mathrm{HCl}, \mathrm{pH}$ 8.2, $193 \mathrm{mM}$ glycine and 15\% methanol to a Hybond-P polyvinylidine fluoride (PVDF) membranes (Pharmacia Amersham Biosystem), for 12 hours at cold room temperature $\left(4^{\circ} \mathrm{C}\right)$ at $400 \mathrm{~mA}$, using a wet-transfer apparatus.

Membranes were incubated for 60 minutes with primary antibody anti-Vinculin diluted 1:75 (Clone VIN-11-5, V 4505 Sigma Chemical). The secondary antibody was alkaline phosphatase conjugated anti mouse IgG diluted 1:10.000 (A 2418 Sigma Chemical), incubated for one hour, and followed by three washes with TBS during one hour. Antibody binding was visualized by exposure to BCIP/NBT (Calbiochem, 203790).

For the detection of Troponin-T fragments, pellet samples were used. After the load, the gel was placed in Comassie Blue (Morrissey, 1981), during four hours, in orbital shaking platform. Later it was discolored with a solution containing $40 \%$ of methanol and $10 \%$ of acetic acid, for one hour. Then the gel was washed with distilled water and was taken photography with a digital camera (Kodak DC120).

\section{Statistical Analysis}

The analysis of the kinetics of the myofibrillar fragmentation index during the 24 hours after the slaughter was made according to the following exponential function (Riley et al., 2003):

MFI $=\mathrm{k}_{0}+\mathrm{k}_{1} \exp \left[\mathrm{k}_{2} \times \mathrm{t}_{\mathrm{i}}\right]+\varepsilon_{\mathrm{i}}$

where: $\mathrm{k}_{0}$ represents maximum MFI 24 hours after slaughter, $\mathrm{k}_{1}$ the difference between initial and maximum MFI, $k_{2}$ the rate of MFI growth, $t_{i}$ is the time (hours) after slaughter and $\varepsilon_{\mathrm{i}}$ is the error associated to data observation. The analysis was carried through the NLMIXED of SAS (2000) procedure. The data of each treatment had been separated in individual curves. Parameters were compared to evaluate differences between treatments. For SF values the ANOVA procedure was used, for a fatorial hierarchical model, with the factors: treatments, slaughter and groups. 


\section{RESULTS AND DISCUSSION}

Kinetics of the myofibrillar fragmentation index (MFI)

Two protein concentrations were used for the determination of MFI, both higher when compared to the method described by Culler et al. (1978). The reason for the use of these concentrations is the fact that very low readings were obtained, different from the readings obtained previously, also in a preliminary assay. For the samples used in this experiment high fragmentation was verified, even after only six hours postslaughter, as it can be observed in the photomicrography (Figure 1). The MFI readings increased linearly with the increase of the protein concentration (Figure 2).

The analyses of the parameters of the model that describe the behavior of the MFI, demonstrated that the extension of fragmentation, represented by $\mathrm{k}_{0}$ and the total difference of the process, represented by $\mathrm{k}_{1}$, was not different for acute heat stressed birds (Figure 3).

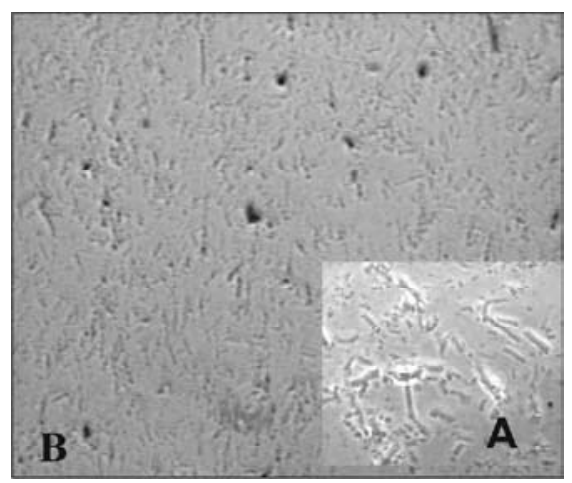

Figure 1 - Photomicrography in contrast of phase of the myofibrillar fraction of breast muscle (objective 10X - B),obtained 6 hours after slaughter of broiler chickens between 40 and 44 days of age, submitted to environmental conditions AHS $\left(35^{\circ} \mathrm{C} ; 75-85 \% \mathrm{RH}\right)$ and $\mathrm{NS}\left(22^{\circ} \mathrm{C}\right.$; $83 \pm 6.6 \% \mathrm{RH}$ ). Objective $40 \mathrm{X}-\mathrm{A}$. (AHS $=$ Acute heat stress; NS $=$ Non-stressed broilers; $\mathrm{RH}=$ Relative humidity).

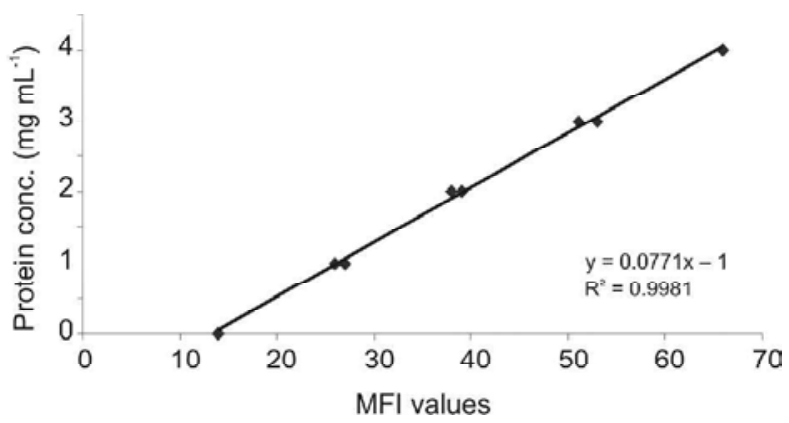

Figure 2 - Myofibrillar fragmentation index (MFI) readings according to protein concentration.
However, when the analysis considered the data of MFI obtained with $0.75 \mathrm{mg} \mathrm{mL}^{-1}$ of protein, the parameter $\mathrm{k}_{2}$ was higher for NS animals, which represents faster rate of fragmentation. This can indicate that AHS may alter the rate of myofibrillar proteolysis. The rate of $\mathrm{pH}$ fall due to acute heat (Sandercock et al., 2001) could be the reason for interference with the proteolytic process. The electric stimulation that causes a faster $\mathrm{pH}$ fall showed a detrimental effect on MFI of the chicken (Veeramuthu \& Sams, 1999).

On the other hand, the model did not detect differences for $1.5 \mathrm{mg} \mathrm{mL}^{-1}$ of protein. Even though the model had shown good convergence and good precision to describe the data for both protein concentrations in the MFI determination, the higher protein concentration could have caused saturation of myofibrillar fragments capable to absorb light, difficulting the detection of small differences in the initial fragmentation phases.

\section{Shear Force (SF)}

The environmental condition did not change the SF values at samples collected 24 hours postslaughter, showing an average of $4.82 \mathrm{kgf}$ for the AHS birds and $4.79 \mathrm{kgf}$ for NS. These results confirm the data of fragmentation, which showed no differences for the extent of fragmentation. Therefore, no differences were expected in SF. These results were in accordance with Bressan \& Beraquet (2002), who reported SF values were not affected by pre-slaughter environmental conditions.

\section{SDS PAGE for Troponin-T}

The color intensity of degradation fragments of Troponin-T in the gel increased for the two sampling times, six and 24 hours after slaughter (Figures 4 and 5, respectively). The appearance of this fragment in the myofibrillar fraction is considered a good indicator of the meat tenderization process (Ho et al., 1994).

For the samples obtained six hours after slaughter, consistent and significant changes in the presence of these fragments were not affected by the environmental condition and $\mathrm{L}^{*}$ values. However, 24 hours after slaughter a differentiated pattern of these fragments seems to occur in AHS and NS animals (see detail Figure 5), independent of the $L^{*}$ value.

\section{SDS-PAGE for the sarcoplasmatic fraction}

The analysis of the SDS-PAGE of the sarcoplasmatic fraction showed the appearance of a band above of $200 \mathrm{kDa}$ six hours after slaughter, characteristic of animals that had presented high $\mathrm{L}^{*}$ value, independently of the environmental condition (see detail 
Figure 6). According to the size of the bands it is probable that this fragment refers to protein or to protein fragments, deriving from the migration between myofibrillar to sarcoplasmatic fractions. The protein migration between the muscular fractions was identified in meats with problems in the functionality (Pietrzak et al., 1997).

\section{Western blot of Vinculin}

The Vinculin appears in the bands of both treatments, being impossible to distinguish alterations due to acute heat stress (Figure 7). This protein of 130 $\mathrm{kDa}$ exerts an important function in the maintenance of the myofibrillar structure, for the linking that ex-

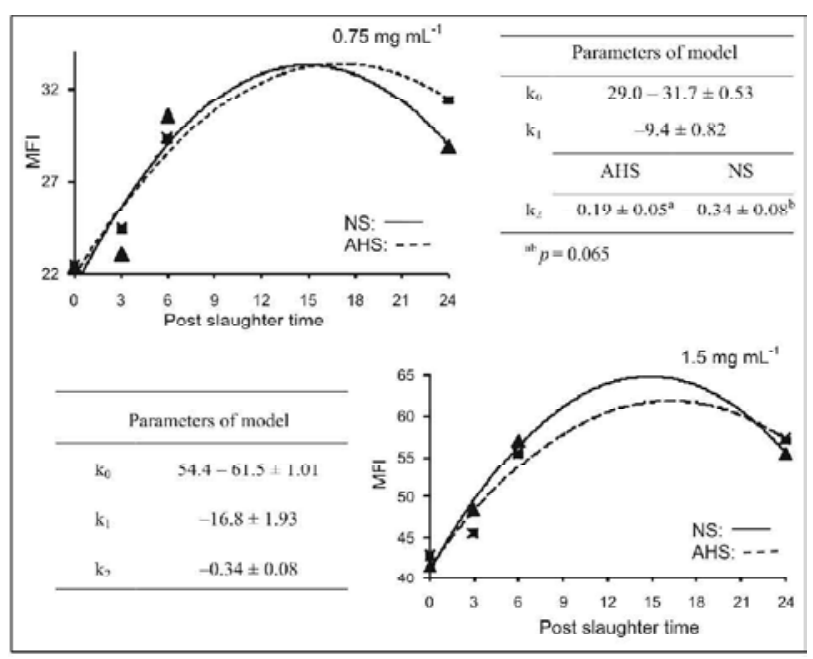

Figure 3 - Kinetics of the Myofibrillar fragmentation index (MFI) verified for protein concentrations of 0.75 and $1.5 \mathrm{mg}$ $\mathrm{mL}^{-1}$ of breast muscle of broiler chickens with ages between 40 and 44 days, submitted to environmental conditions AHS $\left(35^{\circ} \mathrm{C} ; 75-85 \% \mathrm{RH}\right)$ and $\mathrm{NS}\left(22^{\circ} \mathrm{C}\right.$; $83 \pm 6.6 \% \mathrm{RH})$. (AHS = Acute heat stress; $\mathrm{RH}=$ Relative humidity; NS = Non-stressed broilers).

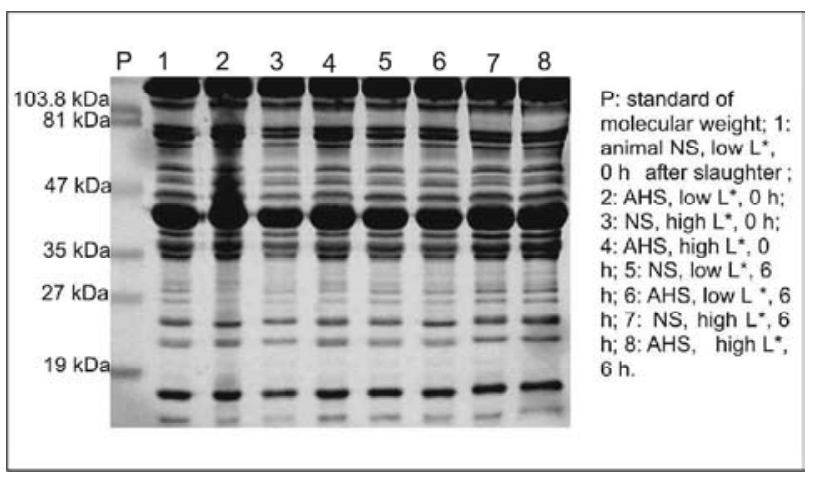

Figure 4 - SDS-PAGE of myofibrillar fraction, at sampling times 0 and 6 hours, with $L^{*}$ values of $<49$ (low) and $>51$ (high) of broilers submitted to environmental conditions AHS $\left(35^{\circ} \mathrm{C} ; 75-85 \% \mathrm{RH}\right)$ and $\mathrm{NS}\left(22^{\circ} \mathrm{C}\right.$; $83 \pm 6.6 \% \mathrm{RH})$. (AHS $=$ Acute heat stress; $\mathrm{RH}=$ Relative humidity; NS = Non-stressed broilers.) erts between $\mathrm{Z}$ disks and $\mathrm{Z}$ disks with sarcolemma, and suffers proteolysis post mortem. For this reason it has been used as an indicative of the meat tenderization in bovines (Koomaraie et al., 1995; Taylor et al., 1995). However, Vinculin was not a good candidate to demonstrate the effect of the environmental condition on myofibrillar proteins.

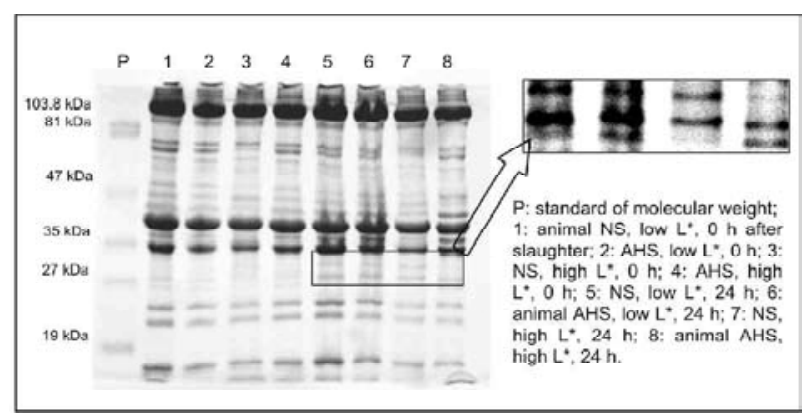

Figure 5 - SDS-PAGE of myofibrillar fraction, at sampling times 0 and 24 hours, with $L^{*}$ values of $<49$ (low) and $>51$ (high) of broilers submitted to environmental conditions AHS $\left(35^{\circ} \mathrm{C} ; 75-85 \% \mathrm{RH}\right)$ and NS $\left(22^{\circ} \mathrm{C} ; 83 \pm 6.6 \%\right.$ $\mathrm{RH})$. (AHS = Acute heat stress; $\mathrm{RH}=$ Relative humidity; NS $=$ Non-stressed broilers.)

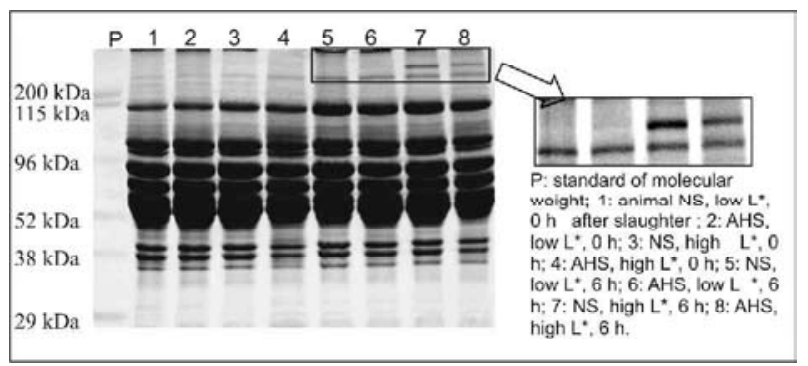

Figure 6 - SDS-PAGE of sarcoplasmatic fraction, at sampling times 0 and 6 hours, with $L^{*}$ values of $<49$ (low) and $>51$ (high) of broilers submitted to environmental conditions AHS $\left(35^{\circ} \mathrm{C} ; 75-85 \% \mathrm{RH}\right)$ and $\mathrm{NS}\left(22^{\circ} \mathrm{C}\right.$; $83 \pm 6.6 \% \mathrm{RH})$. (AHS = Acute heat stress; $\mathrm{RH}=$ Relative humidity; NS = Non-stressed broilers.)

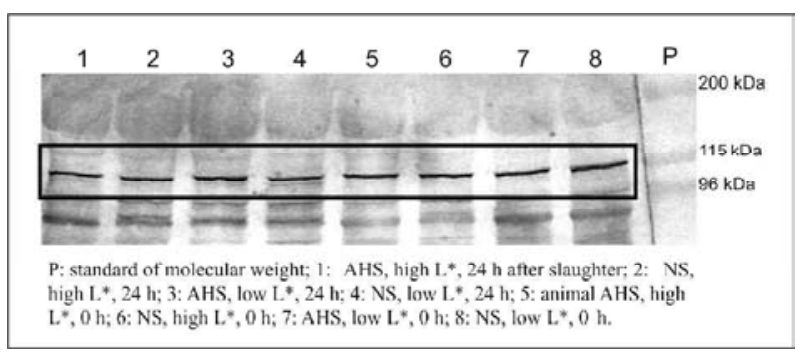

Figure 7 - Western blot of vinculin in myofibrillar fraction at sampling times 0 and 24 hours, with $\mathrm{L}^{*}$ values of $<$ 49 (low) and $>51$ (high) of broilers submitted to environmental conditions AHS $\left(35^{\circ} \mathrm{C} ; 75-85 \% \mathrm{RH}\right)$ and $\mathrm{NS}\left(22^{\circ} \mathrm{C} ; 83 \pm 6.6 \% \mathrm{RH}\right)$. (AHS = Acute heat stress; RH $=$ Relative humidity; NS $=$ Non-stressed broilers). 


\section{CONCLUSIONS}

The rate of myofibrillar fragmentation can be altered by acute heat stress, but the proteolytic extension was not changed. Acute heat stress caused differentiated pattern of appearance of specific myofibrillar fragments, but did not alter shear force values. Modifications in the sarcoplasmatic fraction are observed in pale meat, independent of the pre-slaughter environmental condition.

\section{ACKNOWLEDGEMENTS}

To FAFESP for the financial support (Project 04/06990-3), and CAPES for the graduate scholarship granted to the first author

\section{REFERENCES}

AKSIT, M.; YALCIN, S.; OZKAN, S.; METIN, K. OZDEMIR, D. Effects of temperature during rearing and crating on stress parameters and meat quality of broilers. Poultry Science, v.85, p.1867-1874, 2006.

BARBUT, S. Color measurements for evaluating the pale, soft, exudative (PSE) occurrence in turkey meat. Food Research International, v.26, p.39-43, 1993.

BARBUT, S. Problem of pale, soft, exudative meat in broiler chickens. British Poultry Science, v.8, p.355-358, 1997.

BRESSAN, M.C.; BERAQUET, N.J. Efeito de fatores pré-abate sobre a qualidade da carne de peito de frango. Ciência e Agrotecnologia, v.26, p.1049-1059, 2002.

BRISKEY, E.J. Etiological status and associated studies of pale, soft, exudative porcine musculature. Advanced Food Research, v.13, p.89-105, 1964.

CULLER, R.D.; PARRISH JR., F.C.; SMITH; G.C.; CROSS; H.R. Relationship of myofibril fragmentation index to certain chemical physical and sensory characteristics of bovine longissimus muscle. Journal of Food Science, v.43, p.1177$1180,1978$.

FRONING, G.W.; UIJTTENBOOGAART, T.G. Effect of post mortem electrical stimulation on color, texture, $\mathrm{pH}$, and cooking loses of hot and cold deboned chicken broiler breast meat. Poultry Science, v.67, p.1536-44, 1988.

GORNALL, A.G.; BARDAWILL, C.J.; DAVID, M.M. Determination of serum proteins by means of the biuret reaction Journal of Biological Chemistry, v.177, p.751-760, 1949.

HEDRICK, H.B.; ABERLE, E.D.; FORREST, J.C.; JUDGE, M.D.; MERKEL, R.A. Principles of meat science. 3 ed. Dubuque: Kendall/Hunt, 1994. 354p.

HO, C.Y.; STROMER, M.H.; ROBSON, R.M. Identification of the $30 \mathrm{kDa}$ polypeptide in post mortem skeletal muscle as a degradation product of troponin-T. Biochimie, v.76, p.369375,1994

HONIKEL, K.O.; REAGAN, J.O. Influence of different chilling conditions on hot-boned pork. Journal of Food Science, v.1, p.766-768, 1986.
KOOMARAIE, M.; SHACKELFORD, S.D.; WHEELER, T.L.; LONERGAN, S.M.; DOUMIT, M.E. A muscle hypertrophy in lamb (callipyge): characterization of effects on muscle growth and meat quality traits. Journal of Animal Science, v. 73 , p.3596, 1995.

LAEMMLI, U.K. Cleavage of structural proteins during the assembly of the head bacteriophage T4. Nature, v.227, p.680$685,1970$.

MacBRIDE, M.A.; PARRISH, F.C. The 30,000 dalton component of tender bovine longissimus muscle. Journal of Food Science, v.42, p.1627-1629, 1977.

McCURDY, R.D.; BARBUT, S.; QUINTON, M. Seasonal effect on pale soft exudative (PSE) occurrence in young turkey breast meat. Food Research International, v.29, p.363-366, 1996.

MORRISSEY, D.H. Silver strain for proteins in polyacrilamide gels: a modified procedure with enhanced uniform sensitivity. Analytical Biochemistry, v.117, p.307-310, 1981.

OLSON, D.G.; PARRISH JR., F.C.; STROMER, M.H. Myofibril fragmentation and shear resistance of three bovine muscles during postmortem storage. Journal of Food Science, v.41, p.10361041, 1976.

PIETRZAK, M.; GREASER, M.L.; SOSNICKI, A.A. Effect of rapid rigor mortis processes on protein functionality in Pectoralis Major muscle of domestic turkeys. Journal of Animal Science, v.75, p.2106-2116, 1997.

RILEY, D.G.; CHASE JR., C.C.; PRINGLE, T.D.; WEST, R.L.; JOHNSON, D.D.; OLSON, T.A.; HAMOND, A.C.; COLEMAN, S.W. Effect of sire on $\varnothing$ - and m-calpain activity and rate of tenderization as indicated by myofibril fragmentation indices of steaks from Brahman cattle. Journal of Animal Science, v. 81, p.2440-2447, 2003.

SANDERCOCK, D.A.; HUNTER, R.R.; NUTE, GR.; MITCHELL, M.A.; HOCKING, P.M. Acute heat stress-induced alterations in blood acid-base status and skeletal muscle membrane integrity in broiler chickens at two ages: implications for meat quality. Poultry Science, v.80, p.418-425, 2001.

SAS INSTITUTE. SAS language and procedures: usage; version 8.1. Cary: SAS Institute, 2000.

SOSNICKI, A.A.; GREASER, M.L.; PIETRZAK, M.; POSPIECH, E.; SANTE, V. PSE-like syndrome in breast muscle of domestic turkeys: a review. Journal of Muscle Foods, v.9, p.13-23, 1998.

TAYLOR, R.G. Is Z-disk degradation responsible for post-mortem tenderization Journal of Animal Science, v.7, p.1351-1367, 1995.

VEERAMUTHU, G.I.; SAMS, A.R. Postmortem pH, myofibrillar fragmentation, and calpain activity in pectoralis from electrically stimulated and muscle tensioned broiler carcasses. Poultry Science, v.78, p.272-276, 1999.

WOOD, D.F.; RICHARDS, J.F. Effect of some antemortem stressors on post-mortem aspects of chicken broiler pectoralis muscle. Poultry Science, v.54, p.528-531, 1975.

Received August 10, 2007

Accepted May 06, 2008 